\title{
Hipotetik TGA (Tahmin-Gözlem-Açıklama) döngüsü ile kimyasal değişimin doğasının öğretimi; asit-baz indikatör tepkimesi örneği
}

\author{
Soner ERGÜL ${ }^{1}$, Davut SARITAŞ ${ }^{2}$, Hasan ÖZCAN ${ }^{3, *}$ \\ ${ }^{\text {I} S a m s u n ~ O n d o k u z ~ M a y ı s ~ U ̈ n i v e r s i t e s i, ~ E g ̆ i t i m ~ F a k u ̈ l t e s i, ~ M a t e m a t i k ~ v e ~ F e n ~ B i l i m l e r i ~ E g ̆ i t i m i ~ B o ̈ l u ̈ m u ̈,, ~}$ \\ Samsun \\ ${ }^{2}$ Nevşehir Hacı Bektaş Veli Üniversitesi, Eğitim Fakültesi, Matematik ve Fen Bilimleri Eğitimi Bölümü, \\ Nevşehir \\ ${ }^{3}$ Aksaray Üniversitesi, Eğitim Fakültesi, Matematik ve Fen Bilimleri Eğitimi Bölümü, Aksaray
}

Geliş Tarihi (Received Date): 18.12.2019

Kabul Tarihi (Accepted Date): 21.02.2020

$\ddot{O} z$

Kimyasal değişimin doğasının anlaşılması kimya ögretiminde en temel amaçlardan birisidir. Fen ve kimya ögretiminde en fazla tanınan malzemelerden birisi olan turnusol kâğıdının asidik ve bazik çözeltilerdeki renk değişim olayında değişimin fiziksel mi yoksa kimyasal mı olduğu, kâğıttaki turnusolün asidik mi yoksa bazik mi olduğuna yönelik sorular kimyasal değişimin doğasının anlaşılmasında uygun bir çıkış noktası olabilir. Bu çalışmada fen eğitiminde yaygın bir kullanıma sahip olan Tahmin et-Gözle-Açıkla (TGA) yöntemi temel alınarak hazırlanmış bir öğretim tasarımı sunulmuştur. Tasarım, kimyada kavram yanılgılarının sıkça görüldüğü kimyasal değişimin doğasının öğretimi için yaygın, bilinen malzemeler ile yapılacak gösteri deneylerinin yer verildiği bir etkinlik üzerinden örneklendirilmiştir. Etkinliğin hazırlanmasında fen eğitiminde hedeflenen bilimsel süreç, bilimsel düşünme, bilimsel açıklama becerileri ve kavramsal ögrenme gibi birçok amaç dikkate alınmıştır. Bu bakımdan etkinlik öğrencilerin gözlemlerden yola çıkarak ve mevcut kuramsal içerik bilgisini kullanarak çıkarımlar yapmalarına ve hipotez geliştirmelerine imkân tanımaktadır. Bu çalışma ile geliştirilen ve bir öğrenme döngüsü şeklinde modellenmiş olan etkinlik tasarımının, fen eğitiminde etkililiği bilinen ve güncel birçok özel ögretim yöntemi için de kullanılabilir TGA yönteminin faydalarını içerdiği değerlendirilmektedir.

Anahtar kelimeler: Kimya ĕ̌itimi, kimyasal değişimin doğası, tahmin-gözlem-açıklama, turnusol testi.

Soner ERGÜL, sergul@omu.edu.tr, http://orcid.org/0000-0002-6826-5481

Davut SARITAŞ, davutsaritas@nevsehir.edu.tr, http://orcid.org/0000-0002-5108-4801

*Hasan ÖZCAN, hozcan@aksaray.edu.tr, http://orcid.org/0000-0002-4210-7733 


\title{
Teaching the nature of chemical change through Hypothetical POE (Prediction, Observation, Explanation) cycle: an example of acid-base indicator reaction
}

\begin{abstract}
One of the principal aims of chemistry instruction is understanding the nature of chemical change. In understanding the nature of chemical change, it would be a good starting point to explore the change in the colour of a litmus paper in acidic and basic solutions. The litmus paper is one of the most commonly used papers in chemistry and science. In the current study, an instructional design was proposed by using the Predict-ObserveExplain (POE) technique, which is a commonly used in science education. In the instructional design, common misconceptions experienced by the students were considered. The instructional design was illustrated by an activity in which demonstration experiments were conducted by means of commonly used materials. In designing the activity, many educational targets such as science process skills, scientific thinking, scientific explanation, and conceptual knowledge were considered. Thus, the activity helps students make predictions and develop hypothesis based on observations and preexisting theoretical content knowledge. The current study exemplifies the use of predictobserve-explain technique in an activity modelled as an instructional cycle and suggests that this technique may be used commonly in the teaching of science concepts and topics.
\end{abstract}

Keywords: Chemistry education, the nature of chemical change, predict-observeexplain technique, litmus test.

\section{Giriş}

Bilgilerimizin yapı taşları olan kavramlarımız deneyimlerimize anlam vermede ve gözlemlerimizden çıkarım yapmada belirleyici bir yere sahiptir. $\mathrm{Bu}$ nedenle yapılandırmacı öğrenme paradigmasına dayalı güncel öğretim yaklaşımlarına göre bireylerin önbilgileri ve kavramları öğretimde dikkate alınması gereken önemli unsurlardır (Köseoğlu \& Tümay, 2013). Bireylerin ön bilgileri ile öğrenilen yeni bilgiler arasında bir uyum olması için öğretimde amaçlanan bilgi temel alınarak ön bilgilerin kontrol edilmesi, değiştirilmesi ve gerekli durumlarda yanlışlanması ve terk edilmesi gerekir. Bunun için öğrenen birey açısından gerekli olan şey ikna edici ampirik deneyimlerin yaşanmasıdır. Nitekim epistemolojik açıdan bir bilginin kabul edilebilir olması için gereken ölçütlerden birisi olan mütekabiliyet ölçütüne göre doğru bilgi olguyu karşılayan bilgidir (Çüçen, 2009). Bu tür ikna edici bilgiler genellikle nesnel gözlemlerden, ampirik deneyimlerden elde edilir.

Gözlemler veya ampirik deneyimler söz konusu olduğunda fen öğretiminde buluş yolu ile öğrenme önemli bir yere sahiptir. Bruner tarafından geliştirilen buluş yoluyla öğrenme, öğrencinin kendi etkinliklerine ve gözlemlerine dayalı olarak yargıya varmasını teşvik eder (Senemoğlu, 2011). Buluş temelli bir fen öğretiminin özünde gözleme imkân tanıyan uygulamalar (ör. gösteri yöntemi, tümevarım laboratuvarı vb.) yer almaktadır (Çepni, 2012). Bu bağlamda öğrenenler gözlemlerler ve bunları anlamlandırarak bilgiler üretirler. Bu nedenle özellikle kimya öğretiminde doğrudan gözleme imkân veren 
uygulamalı etkinliklerin yer aldığı laboratuvar yöntemi ve gösteri deneyleri oldukça önemlidir. Öğretmenler öğrenilmesi zor olan kimya kavramlarını bu tür yöntemlerle ve daha kolay somutlaştırılabilecekleri ilginç gösteri deneylerinden yararlanmalıdır (Eilks \& Gulaçar, 2016). Diğger yandan bilimsel araştırma sürecinin vaz geçilmez bir unsuru olan gözlem aynı zamanda bilim insanlarının buluşlarında etkili olan temel bir beceridir (Martin, 1997). Ancak gözlemler aracılığ ile elde edilen bilginin deneyimlenen olgu hakkında tam anlamı ile bilgi vermesi için olguyu betimlemenin yanında açıklaması da gerekir. Nitekim deney yapma, gözlem yapma haricinde; sonuç çıkarma, hipotez kurma vb. beceriler, bir yandan fen eğitiminin vaz geçilmez amaçlarından olan bilimsel süreç becerileri (Tan ve Temiz, 2003) kapsamında olmakla birlikte diğer yandan gözlem ve çıkarım farkını anlama da bilimin doğasının yönlerinin (Lederman, Lederman \& Antink, 2013) anlaşılması için önemlidir.

Gözlemlenen bir olgunun bilimsel bir biçimde açıklanması için farklı tür kavramlara ihtiyaç vardır. Bunlardan bazıları betimsel nitelikte kavramlar iken, bazıları açıklayıcı niteliği ağır basan (kuramsal) nitelikli kavramlardır. Bu bağlamda, betimsel nitelikteki kavramlar; doğrudan gözlem ve ölçüm yoluyla elde edilen nitel ve nicel verilerden hareketle oluşturulan kavramlar iken, kuramsal nitelikteki kavramlar; gözlemlenen olguyu açıklamak için dolaylı verilerden hareketle oluşturulan kavramlardır (Lawson, 1995; Lawson, Alkhoury, Benford, Clark, \& Falconer, 2000). Örneğin renk, renk değişimi, asit, baz, asidik, bazik, fiziksel özellik, kimyasal özellik, fiziksel ve kimyasal değişim kavramlarının spektroskopi, atom teorisi, denge teorisi, asit-baz teorileri ile ilişkili olması nedeniyle teorik boyutları bulunmaktadır. Bu nedenle bir gözlemden yapılan çıkarımın kabul edilmesi, başka bir ifade ile bilimsel açıdan kabul edilen açıklamalar ile uyumlu olması için gözlem öncesi bilgiler ve tahminler ile karşılaştırılması ve bilimsel olanlar merkeze alınarak test edilmesi gerekir. Bu nedenle gözlemin öncesi ve sonrasının birleştiren bir yaklaşıma ihtiyaç vardır. Bu noktada akla gelen ise TGA'dir.

\section{Yöntem}

Tahmin et-gözlemle-açıkla (TGA) öğrencilerin bir olguya ilişkin gerekçeli tahminler üretmeleri, olguyu bilinçli bir şekilde gözlemlemeleri ardından gözlem ve tahminlerini karşılaştırarak olguya yönelik açıklamalar yapmalarına dayanan bir etkinliktir (Kearney, Treagust, Shelley \& Zadnik, 2001; Atasoy, 2004). Yaygın olarak teknik veya yöntem olarak ifade edilen TGA hem grup hem de bireysel etkinliklerle yapılabilir üç aşamadan oluşmaktadır; (1) Tahmin aşaması; öğrencilere sorular aracılığı henüz gözlemlemedikleri bir olgu hakkında gerekçeli tahminler oluşturmaları ve bunları kaydetmeleri sağlanır. Bu aşama söz konusu olgu ile ilgili öğrencilerin ön bilgileri, kavram yanılgıları, fikir ve bilimsel inançlarını ortaya çıkarmak açısından önemlidir (Kearney, 2004) (2) Gözlem aşaması; öğrencilerin ilk bakışta açıklamakta zorlanacağı ve zihinsel olarak çelişki yaratacak bir olgunun gözlenmesi sağlanır (White \& Gunstone, 1992). Bu aşamada öğrencilerin ön tahminlerine bağlı olarak beklentileri ve ön bilgilerinin gözlemi etkilemesi mümkündür (Kearney, 2004). Doğru bir gözlem yapılması için olgunun tekrarlanması gerekebilir, ayrıca gözlemlerin kaydedilmesi sağlanmalıdır (Köseoğlu, Tümay \& Kavak, 2002). (3) Açıklama aşaması; öğrencilerin kayıt altına aldıkları tahminleri ve gözlemleri arasında fark olup olmadığını, varsa bunun nedenini düşündükleri ve çıkarımlarını açıkladıkları ve genel olarak öğrencilerin zorlandıkları bir aşamadır (Kearney, 2004). TGA'da öğretmenin fikir üretmede ve çıkarım yapmada 
motive edici ve rehberlik edici bir rolü vardır (Köse, Çoştu ve Keser, 2003). Öğretmen doğrudan bir açıklama yapmasa da gözlem-tahmin çelişkisini bir firsat bilerek ve gözlemi temel alarak öğrencileri bilimsel bilgilere ikna edici bir şekilde yönlendirebilir. Bu şekilde gözlemle çelişen tahminlerini belirleyen kavram yanılgılarını giderme firsatı bulabilir.

Karmaşık bir yapısı olmayan TGA'ın oldukça etkili bir yöntem olduğu ifade edilmektedir (Kearney, vd. 2001). Literatür incelendiğinde fen eğitiminde önerilen TGA'ın birçok kimya konusunda akademik başarıdan tutuma ve kimya kavramlarının öğretimine kadar birçok boyutta katkı sağladığı görülmektedir (Köseoğlu, Tümay \& Kavak, 2002; Karaer, 2007; Smith, Edionwe \& Michel, 2010; Durmuş, 2014; Kıryak \& Özdilek, 2019).

\section{Teorik çerçeve}

Kimya doğrudan gözlemlenemeyen olgulara (mikro/sub-mikro) yönelik bilgileri yoğun olarak kullanan bir bilim olduğu için öğrenenlerde kavram yanılgıları oluşma olasıllı̆̆ fazladır (Sarıtaş ve Tufan, 2013). Kavram yanılgılarının sıkça rastlandığı konuların arasında kimyasal değişim, asit ve bazlar, denge vb. de vardır (Sökmen, Bayram \& Yılmaz, 2000; Morgil, Erdem \& Yılmaz, 2003). Bunlardan kimya açısından temel oluşturanı şüphesiz kimyasal değişim kavramının doğasının hedeflendiği kimyasal değişim konusudur. Kimyasal değişimin üzerine yapılan çok sayıda çalışma her seviyeden öğrencilerin kimyasal değişimi anlamada zorlandığını göstermektedir (akt. Erol, 2016).

Yapılan çalışmalar öğrencilerin kimyasal değişimi günlük yaşamdaki deneyimleri ile bağlantılı olarak anlamlandırdıkları (Schollum \& Osborne, 1985; Atasoy, Genç, Kadayıfçı \& Akkuş, 2007), maddenin yeni özelliklerinin ortaya çıkışını genellikle renk , koku ve tat gibi gözlemlenebilir nitelikler ile ilişkilendikleri, özellikle renk değişiminin maddenin fiziksel, kimyasal değişimindeki mahiyetini ve kimyasal değişimin kuramsal boyutlarını (ör. tanecik düzeyinde) anlamakta zorlandıklarını göstermektedir (Tsaparlis, 2003; Stravridou \& Solomanidu, 1998; Papageorgiou, Stamovlasis \& Johnson, 2010). Diğer yandan öğrencilerin fiziksel ve kimyasal değişim kavramını ayırt etmelerinde ve kimyasal değişimi anlamalarında en fazla yanılgı yaratan nedenlerinin başında "geri dönüşümlülük”" (tersinirlik) ölçütü ile olguları değerlendirmeleri gelmektedir (Çalık \& Ayas, 2005; Atasoy vd. 2007). Ayrıca bir öğretim planlamasında içeriğin kimyasal değişimin ilişkili olduğu birçok konu ve kavramla anlamlı bir bütün oluşturacak şekilde düzenlenmemesi de kimyasal değişimin doğasının anlaşılmasını engellemektedir (Johnson, 2000).

Bu bağlamda, gözlemlenebilir bir değişim, tersinirlik ve gereken kuramsal boyut bir arada düşünüldüğünde kimyasal değişimin doğasının anlaşılması için gereken ilişkisel ve bütüncül bir öğretim tasarımında ilk akla gelen olgulardan birisi turnusolün renk değişimidir. $\mathrm{Bu}$ olgu esasen kimyanın diğer bir önemli konusu olan asit ve bazlar konusundan aşina olunan bir olgudur. Tüm öğretim kademelerinde önemli bir yere sahip asitler ve bazlar konusundaki kavramlar birçok kimya konusuyla (ör. çözeltiler, derişim, indirgenme, yükseltgenme, kimyasal denge, organik kimya) yakından ilişkilidir ve bunlara temel oluşturmaktadır. Bu nedenle asit ve bazlar konusunda oluşacak kavram yanılgıları bu konuların öğrenilmesini olumsuz etkileyecektir (Yalçın-Çelik, Turan-Oluk, Üner, Ulutaş \& Akkuş, 2017). 
Kimyasal değişimle doğrudan ilişkili olmasa da turnusolün renk değişimi ile ilgili olarak asit-baz tepkimelerinde tersinirlik ve bağlamında denge teorisi üzerine çok az çalışma bulunmaktadır (Eilks, Gulacar, \& Sandoval, 2018; Coleman \& Randall 2003; Ihde, 1989). Örneğin, Eilks ve diğ. (2018), yaptıkları çalışmada, bir kimyasal tepkimede asitler ve bazlar arasındaki ilişkiyi açıklamak amacıyla gözlem yoluyla nitel verilerin elde edildiği, zeolitler gibi katı haldeki asitlerin özelliklerine odaklanan bir gösteri deneyi planlamışlardır. Bu gösteri deneyi öğrencilerin gözlem yoluyla elde ettikleri bir fiziksel fenomeni analiz edebildiklerini, ayrıca tepkimedeki bir ürünün eklenmesi durumunda, tepkimenin yönünün nasıl değiştiğini göstererek Le Châtelier'in ilkesini kavradıklarını belirtmişlerdir. Ihde (1989) yaptığı çalışmada, etki-tepki ilkesi üzerinden kimyasal değişimin açıklanabileceğini, fen eğitimi ve kimya eğitimine de uygulanabilir olduğunu belirtmiştir. Bu bağlamda, günlük yaşantının kimyasal dinamik dengenin Le Chatelier İlkesi ile devam ettiği düşüncesi üzerinden bazı analojiler geliştirmiş ve geliştirdiği analojiler ile eğitim verdiği öğrencilerin etki-tepki ilkesi üzerinden kimyasal dinamik denge teorisi ve bağlamında kimyasal değişimde tersinirliği daha kolay öğrendiklerini belirtmiştir.

$\mathrm{Bu}$ genel bağlamdan hareket edildiğinde bu çalışmada bilginin bir bütün ve ilişkisel olarak yapılandırıldığını öngören yapılandırmacı paradigma çerçevesinde farklı sınıf seviyelerinde kendini gösteren kimyasal değişimi anlama sorunu ve oluşan kavram yanılgılarını önlemede kullanılabilir bir öğretim tasarımı önerilmektedir. Tasarım, güncel fen öğretiminde önemli bir yeri olan TGA yöntemi temel alınarak olağan kimya sınıflarında sıkça rastlanabilecek bir olgu olan turnusolün renk değişimi olgusu üzerinden bir etkinlikle örneklendirilmiştir.

TGA'nın aşamalarının hipotez geliştirme ve test etme şeklinde bir döngü oluşturduğu tasarıma örnek olarak verilen etkinlikte önerilen deneyler pratikte yaygın bir şekilde kullanılan "Bir maddede gerçekleşen fiziksel değişim tersinir iken, kimyasal değişim tersinmezdir" kavram yanılgısını giderebilecek ve "fiziksel değişimler bazı durumlarda tersinir iken bazı durumlarda tersinmez, kimyasal değişimler bazı durumlarda tersinirken bazı durumlarda tersinmezdir" genellemesine ulaşmayı sağlayacak şekilde organize edilmiştir.

\section{1. Ö̆ gretim tasarımının formal yapısı}

TGA'ya dayalı öğretim tasarımı, Şekil 1'de de görüldüğü gibi döngüsel olarak iki temel süreçten oluşmaktadır. Bu bağlamda hazırlanan örnek bir etkinlik aşamalarıyla birlikte devamında Tablo 1'de paylaşılmaktadır. 


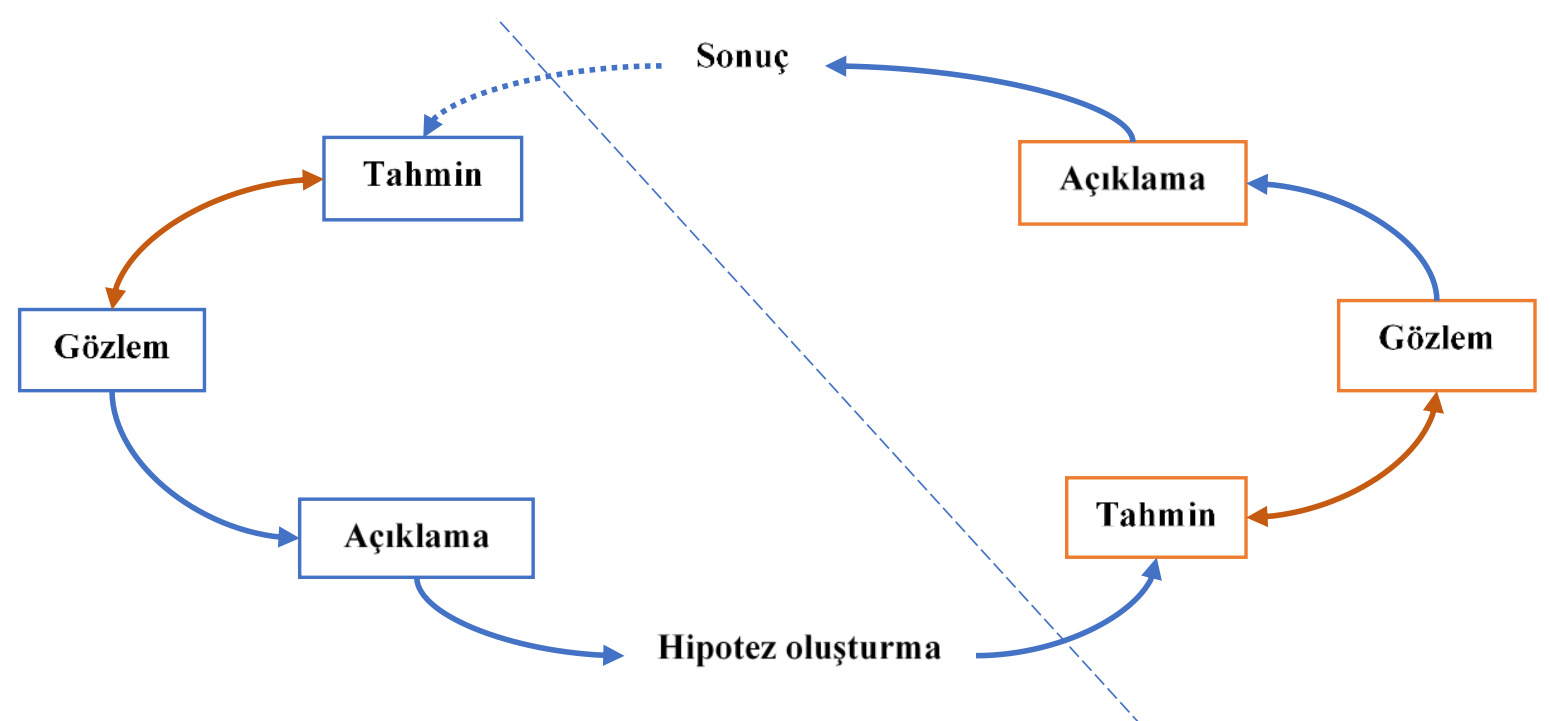

Şekil 1. Entegre hipotetik-TGA (Tahmin et-Gözle-Açıkla) döngüsü.

Tablo 1. Örnek etkinlik ve aşamaları.

\begin{tabular}{|c|c|}
\hline \multicolumn{2}{|c|}{ A. Hipotez geliştirme } \\
\hline Tahmin-A1 & $\begin{array}{l}\text { Süzgeç kağıdının asit ve baz çözeltilerindeki davranışının tahmin edilmesi } \\
\text { ve tanımlanması. }\end{array}$ \\
\hline Gözlem-A1 & $\begin{array}{l}\text { Süzgeç kağıdının } 0.1 \mathrm{M} \mathrm{NaOH} \text { ve } 0.1 \mathrm{M} \mathrm{HCl} \mathrm{çözeltilerindeki} \mathrm{davranışını} \\
\text { gözlem yoluyla incelenmesi (Deney-1) ve gözlemlerin tanımlanması. } \\
\text { Örneğin; } \\
\text { Süzgeç kâğıdı } 0.1 \mathrm{M} \mathrm{HCl} \mathrm{çözeltisine} \mathrm{daldırıldığında} \mathrm{renk} \mathrm{değişimi} \\
\quad \text { olmamıştır. } \\
\begin{array}{l}\text { Süzgeç kâğıdı } 0.1 \mathrm{MaOH} \text { çözeltisine daldırıldığında renk değişim } \\
\quad \text { olmamıştır. }\end{array}\end{array}$ \\
\hline Tahmin-A2 & $\begin{array}{l}\text { Mavi ve kırmızı turnusol kağıdının } 0.1 \mathrm{M} \mathrm{NaOH} \text { ve } 0.1 \mathrm{M} \mathrm{HCl} \\
\text { çözeltilerindeki davranışının gözlem yolu ile incelenmesi (Deney-2) ve } \\
\text { gözlemlerin tanımlanması. } \\
\text { Örneğin; } \\
\text { Mavi turnusol kâğıdının } 0.1 \mathrm{M} \mathrm{NaOH} \text { çözeltisinde rengi değişmez iken, } 0.1 \\
\quad \text { M HCl çözeltisinde rengi kirmızlya dönüşmüştür. } \\
\text { Kırmızı turnusol kâğldının } 0.1 \mathrm{M} \mathrm{HCl} \mathrm{çözeltisinde} \mathrm{rengi} \mathrm{değişmez} \mathrm{iken,} 0.1 \\
\quad \text { M NaOH çözeltisinde rengi maviye dönüşmüştür. }\end{array}$ \\
\hline Açıklama-A1 & 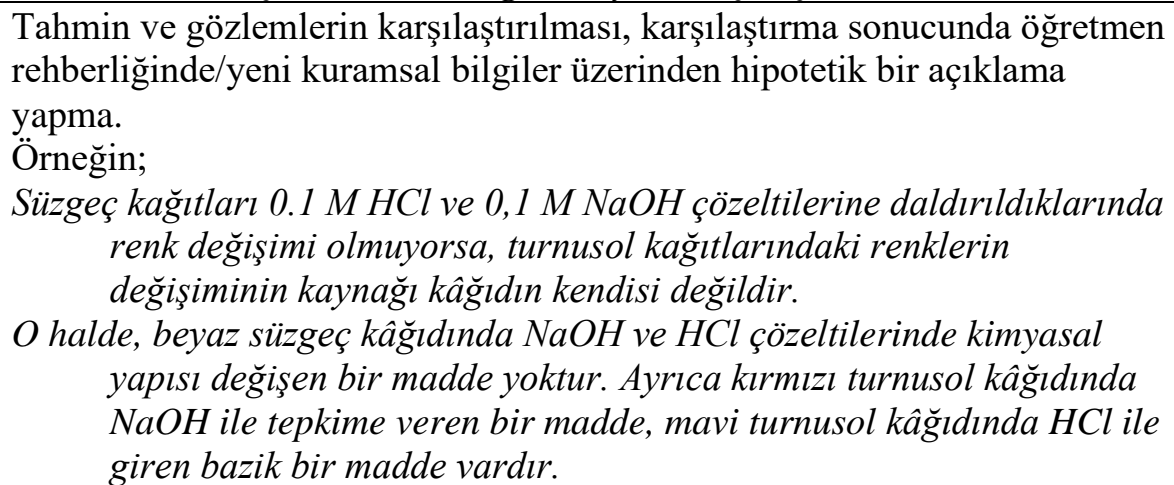 \\
\hline
\end{tabular}


Tablo 1. (Devam1).

\begin{tabular}{|c|c|}
\hline \multicolumn{2}{|l|}{ Hipotez } \\
\hline \multicolumn{2}{|c|}{$\begin{array}{l}\text { Açılamadan yola çıkarak test edilebilir hipotez(ler) üretme. } \\
\text { Örneğin; } \\
\text { H1. Mavi turnusol kâğıdındaki madde baziktir ve asitler ile tepkimeye girer, klrmızı turnusol } \\
\quad \text { kâğlındaki madde asidiktir ve bazlar ile tepkimeye girer; renk değişimi olur. } \\
\text { H2. Bu iki madde diğer asit ve bazlar ile tepkime vererek renk değiştirir. }\end{array}$} \\
\hline \multicolumn{2}{|c|}{ B. Hipotez test etme } \\
\hline Gözlem-B1 & 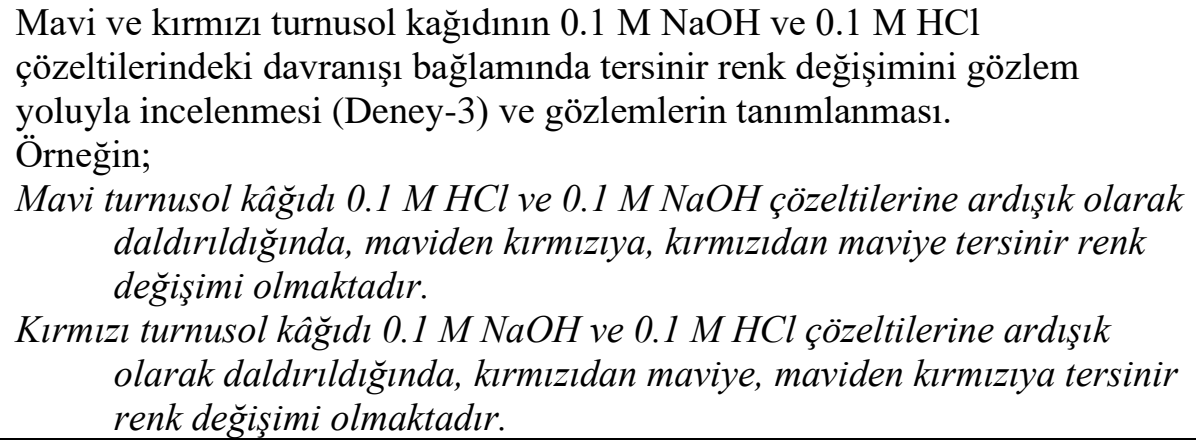 \\
\hline Tahmin-B2 & $\begin{array}{l}\text { (H2'e ilişkin olgusal tahminlerin yapılması) Turnusol testi ile içeriği } \\
\text { bilinmeyen örnek çözeltilerin (X ve Y) asidik ve bazik özelliğinin tahmin } \\
\text { edilmesi ve tanımlanması. }\end{array}$ \\
\hline Gözlem-B2 & 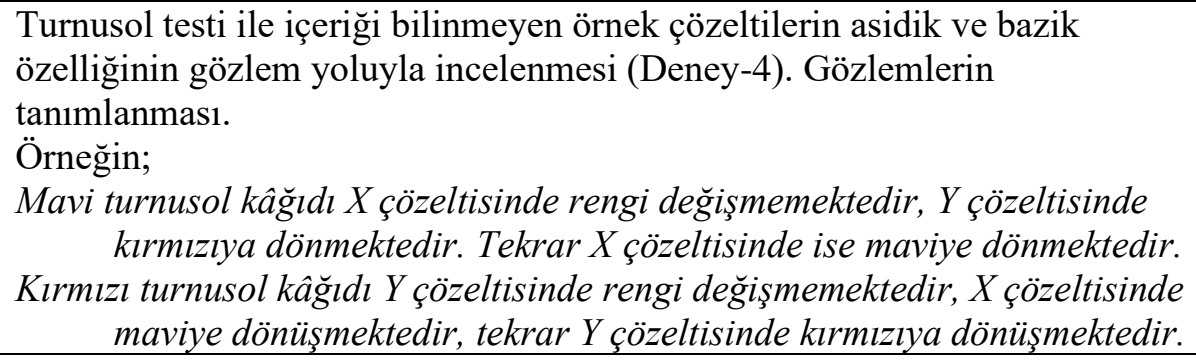 \\
\hline Açıklama-B2 & $\begin{array}{l}\text { Tahmin ve gözlemlerin karşılaştırılması, karşılaştırma sonucunda öğretmen } \\
\text { rehberliğinde/yeni kuramsal bilgiler üzerinden hipotetik bir açıklama } \\
\text { yapma. } \\
\text { Örneğin; } \\
\text { Turnusol kâğıdı farklı asit ve baz çözeltilerinde ardışı olarak birbirine } \\
\text { dönüşen renkler veriyorsa renk veren maddeler temel de aynı } \\
\text { maddeden kaynaklanmaktadır. } \\
\text { O halde; turnusol kağıdındaki indikatör (madde) bir denge tepkimesine göre } \\
\text { hem asidik hem bazik forma dönüşmektedir ve bu özelliği sayesinde } \\
\text { hem asit hem de bazlarla kimyasal olarak değişerek renk değişimine } \\
\text { neden olmaktadır. }\end{array}$ \\
\hline \multicolumn{2}{|l|}{ Sonuç } \\
\hline \multicolumn{2}{|c|}{$\begin{array}{l}\text { Tüm gözlemler ve açıklamalar üzerinde bir sonuca ulaşma. Örneğin; } \\
\text { Turnusolun renk değişimi moleküler yapısının değişimine neden olan tersinir bir tepkimeye } \\
\text { dayandığı için kimyasaldır. }\end{array}$} \\
\hline
\end{tabular}

*Deney planları ve ögretmenler için gerekli kuramsal bilgiler Ek-1 ve 2'de yer almaktadır.

Konunun derinliğine göre döngü devam ettirilebilir. Etkinlik sürecinde TGA'ın genel kullanımında yapılması gerekenlerin haricinde bu çalışmada tanımlanan formal yapı çerçevesinde bazı öğretmen yönergeleri verilebilir;

Tahmin aşamaları 
$\mathrm{Bu}$ aşamalarda öğrencilerin hipotez geliştirmeleri bireysel veya grup çalışması ile sağlanabilir. Bu noktada argümantasyon gibi bilimsel açıklama ve gerekçelendirmeye dayalı yöntemler kullanılabilir. Ayrıca hipotezlerin ifade edilmesinde ve açıklamalarda bilim insanlarının gözlemlerinden çıkarım yaparken kullandıkları akıl yürütme biçimine karş1lık gelen dilsel formlara (ör. hipotetik argüman kalıb1; "eğer ... ve ... ise ... velama ... bu yüzden ... ”, ... Lawson, 2009) yönlendirilmesi sağlanabilir.

\section{Açıklama aşamaları}

$\mathrm{Bu}$ aşamalarda öğrencilerin tahmin aşamalarında oluşturdukları hipotetik tahminleri test etmede gözlem verilerinin yanı sıra mevcut bilimsel kuramsal nitelikli bilgiler ile karşılaştırılarak test etmeleri sağlanabilir. Bu noktada bilimsel kaynaklara ulaşmaları için yönlendirilebilir. Başka bir ifade ile TGA aşamalarına araştırma-inceleme aşamasının entegre edilmesi sağlanabilir (ör. Hilario, 2015). Ayrıca ulaşılan bilimsel bilgileri süreç içerisindeki açıklamalarda gerekçelendirme amaçlı kullanmaları için yönlendirilebilir. Bu şekilde ögrencilerin incelenen olguya yönelik betimlemelerinin bu bilgiler ile kuramsal açıklama niteliğine dönüşmesi sağlanır.

\section{Sonuç, tartışma ve öneriler}

Bu çalışmada önerilen tasarım fen eğitiminde kavram öğretiminde etkili olduğu bilinen güncel bir yöntem olan (Ruscuklu \& Özdilek, 2019) TGA'ya dayanmaktadır. TGA'nın doğası gereği bu çalışmada önerilen etkinlik ve içerisindeki gösteri deneyleri gözlem, deney yapma, çıkarım yapma vb. becerileri üzerine kurgulanmıştır. Bu nedenle birçok açıdan başta bilimsel süreç becerileri olmak üzere beceri odaklı bir öğretim (ör. MEB, 2005, 2013, 2018) için uygundur. Nitekim bilimsel süreç becerileri, birçok bilimsel alana uygulanabilen ve bilim insanlarının davranışlarını yansıtan genellikle aktarılabilir yetenekler kümesidir (Padilla, 1990). Diğer taraftan bu çalışmada önerilen kavramsal yaklaşım ve örnek etkinliğin ilgilendiği sorun bağlamında düşünüldüğünde esasen gözlem ve çıkarım arasındaki farkı temel almakta ve buna deney tabanlı bir öneri sunmaktadır. Bu nedenle yaygın bilimin doğası hedef anlayışlarında ifade edilen "gözlem ve çıkarım farkı", "bilimsel bilginin ampirik doğası” vb. (Lederman vd., 2003) bağlamında uygun müdahaleler ile öğrenci anlayışlarına katkı sağlayabilir.

Ayrıca örnek verilen etkinlik çerçevesinde öğretim tasarımı öğretmenlerin kimyasal değişim konusunda öğretim planlamasında faydalı olabilir. Nitekim öğretmen adaylarının örnekte verilen kimyasal değişim konusu ile ilgili planlama yapmada zorlandıkları bilinmektedir (Del Pozo \& Porlan, 2001). Ekte öğretmenler için etkinliğe yönelik verilen deney bilgileri ve kuramsal bilgiler oldukça geniş tutulmuştur. $\mathrm{Bu}$ sayede farklı seviyelerde (orta öğretim ve lisans) bilgiler uygun bir didaktik dönüşlümle seviye uygun olarak ayarlanabilir. Nitekim kimyasal değişim hemen her seviyede anlaşılması zor bir konudur (Erol, 2016). Ayrıca kimyasal değişimin bilgileri daha üst düzey bilgiler ile ilişkisi kurulabilir ve bu konuda alt sevilerde oluşan kavram yanılgıların da giderme fırsatı olabilir.

Etkinlik literatürde kavram yanılgısı sıkça karşılaşılan temel bir konuyu yine kavram yanılgısı sıkça karşılaşılan diğer önemli konular ile ilişkilendirmekte (ör. asit ve bazlar, denge, tersinirlik vb.) ve bunların ilişkilerinin anlamlı bir biçimde kurulması için bir zemin oluşturmaktadır. Bu nedenle tasarımın birbirinden izole olarak ele alınan bu kavram yanılgılarının gidermekte daha avantajlı olduğu düşünülebilir. Özetle, tasarımı 
gereği kimyanın deneysel doğasına uygun hem de bilimsel düşünme ve bilimsel süreç becerilerini geliştirme boyutlarında katkı sunması olasıdır.

\section{Kaynaklar}

[1] Akgün, A. \& Gönen, S., Çözünme ve fiziksel değişim ilişkisi konusundaki kavram yanılgılarının belirlenmesi ve giderilmesinde çalışma yapraklarının önemi, Elektronik Sosyal Bilimler Dergisi, 3(10), 22-37. (2004).

[2] Atasoy, B., Fen öğrenimi ve öğretimi, (Gözden Geçirilmiş 2. Baskı), Ankara: Asil Yayınc1lik, (2004).

[3] Atasoy, B., Genç, E., Kadayıfçı, H. \& Akkuş, H., 7. sınıf öğrencilerinin fiziksel ve kimyasal değişmeler konusunu anlamalarında işbirlikli öğrenmenin etkisi, Hacettepe Üniversitesi Ĕgitim Fakültesi Dergisi, 32, 1221, (2007).

[4] Coleman W. F. \& Fedosky E. W., From our peer-previewed collection, Journal of Chemical Education, 80(4), 456, (2003).

[5] Çalık, M. \& Ayas, A., A comparison of level of understanding of eighthgrade students and science student teachers related to selected chemistry concepts, Journal of Research in Science Teaching, 42(6), 638-667, (2005).

[6] Çepni, S. Kuramdan uygulamaya fen ve teknoloji öğretimi. Ankara: Pegem Yayıncilik, (2012).

[7] Çüçen, A. K., Bilgi felsefesi. Bursa: Asa Kitabevi, (2009).

[8] Durmuş, A., TGA yöntemine dayalı laboratuvar uygulamalarının fen bilgisi öğretmen adaylarının "1sı ve sıcaklık" konusunu anlamalarına etkisi. Yüksek Lisans Tezi, KTÜ Eğitim Bilimleri Enstitüsü, Trabzon, (2014).

[9] Eilks, I., \& Gulacar, O., A colorful demonstration to visualize and inquire into essential elements of chemical equilibrium, Journal of Chemical Education, 93(11), 1904-1907.

[10] Eilks, I., Gulacar, O., \& Sandoval, J. (2018). Exploring the mysterious substances, $\mathrm{X}$ and $\mathrm{Y}$ : Challenging students' thinking on acid-base chemistry and chemical equilibrium, Journal of Chemical Education, 95(4), 601-604, (2016).

[11] Çayan, Y. ve Ergül, S., Fiziksel ve kimyasal değiş̧im ile renk değişimi bağlamında yeni bir deneysel yöntem, Journal of Research in Education and Teaching, 3 (4), 168-179, (2014a).

[12] Ergül, S., Hipotez test etme temelli fiziksel/kimyasal değişim ile renk değişimi ilişkisinin ögretimi, Journal of Research in Education and Teaching, 3(4), 392-404, (2014b).

[13] Erol, N., Orta öğretim öğrencilerinin kimyasal ve fiziksel değişmelerle ilgili yanlış kavramalarının incelenmesi. Yayınlanmamış Yüksek Lisans Tezi, Balıkesir Üniversitesi, Fen Bilimleri Enstitüsü, Balıkesir, (2016).

[14] Gensler, W. J., Physical versus chemical change, Journal of Chemical Education, 47(2), 154, (1970).

[15] Hilario, J. S., The use of predict-observe-explain-explore (POEE) as a new teaching strategy in general chemistry-laboratory, International Journal of Education and Research, 3(2),37-48, (2015).

[16] Ihde, J., Le Châtelier and chemical equilibrium, Journal of Chemical Education, 66(3), 238, (1989).

[17] Johnson, P., Developing students' understanding of chemical change: what should we be teaching, Chemistry Education: Research and Practice, 1(1), 77-90, (2000). 
[18] Karaer, H., Yapılandırıcı öğrenme teorisine dayalı bir laboratuvar aktivitesi (Kromotografi Yöntemi ile Mürekkebin Bileşenlerine Ayrılması), Kastamonu Ĕgitim Dergisi, 15(2), 591-602, (2007).

[19] Kearney, M., Classroom use of multimedia-supported predict-observe- explain tasks in a social constructivist learning environment, Research in Science Education, 34, 427-453, (2004).

[20] Kearney, M., Treagust, D., Shelley Y \& Zadnik M., Student and teacher perception of the use of multimedia supported predict- observe- explain task to probe understanding, Reseach in Science Teaching, 31, 539- 615, (2001).

[21] Kıryak, Z. \& Özdilek, Z., Tahmin-açıklama-gözlem-açıklama yönteminin sekizinci sınıf öğrencilerinin asit yağmurları konusundaki kavramsal anlama düzeylerine etkisi, Mehmet Akif Ersoy Üniversitesi Eğitim Fakültesi Dergisi, 51, 216-240, (2019).

[22] Kolb, D. (1979). The pH concept, Journal of Chemical Education, 56(1), 51-53

[23] Köse, S., Coştu, B \& Keser Ö F., Fen konularındaki kavram yanılgılarının belirlenmesi: TGA yöntemi ve örnek etkinlikler, Pamukkale Üniversitesi Eğitim Fakültesi Dergisi,13(1), 43- 53, (2003).

[24] Köseoğlu, F. \& Tümay, H., Bilim eğitiminde yapılandırıcı paradigma teoriden öğretim uygulamalarına. Ankara: Pegem Yayıncılık, (2013).

[25] Köseoğlu, F., Tümay, H. ve Kavak, N., Yapılandırıcı öğrenme teorisine dayanan etkili bir öğretim yöntemi-tahmin et-gözle-açıkla- "buz ile su kaynatılır mı ?", V. Ulusal Fen Bilimleri ve Matematik Eğ itimi Kongresi, ODTÜ, Aralık, Ankara, Bildiriler Kitab1 I, 670 - 675, (2002).

[26] Lawson, A. E., Science teaching and the development of thinking. Belmont, CA: Wadsworth, (1995).

[27] Lawson, A. E., Alkhoury, S., Benford, R., Clark, B. R., \& Falconer, K. A., What kinds of scientific concepts exist? Concept construction and intellectual development in college biology, Journal of Research in Science Teaching: The Official Journal of the National Association for Research in Science Teaching, 37(9), 996-1018, (2000).

[28] Lawson, A. E., Basic inferences of scientific reasoning, argumentation, and discovery, Science Education, 94 (2), 223-364, (2009).

[29] Lederman, N.G., Lederman, J.S., \& Antink, A., Nature of science and scientific inquiry as contexts for the learning of science and achievement of scientific literacy, International Journal of Education in Mathematics, Science and Technology, 1(3), 138-147, (2013).

[30] del Pozo, R. \& Porlan, R., Spanish prospective teachers' initial ideas about teaching chemical change, Chemistry Education: Research and practice in Europe, 2(3), 265-283, (2001).

[31] Martin, D., Elementary science methods: A constructivist approach. New York: Delmar, (1997).

[32] MEB [Türkiye Cumhuriyeti Milli Eğitim Bakanlığı Talim ve Terbiye Kurulu Başkanlığg1, İlköğretim fen ve teknoloji dersi öğretim programı ve kılavuzu, Ankara: Devlet Kitapları Müdürlüğü, (2005).

[33] MEB [Türkiye Cumhuriyeti Milli Eğitim Bakanlığı Talim ve Terbiye Kurulu Başkanlığg1], İlköğretim kurumları (ilkokullar ve ortaokullar) fen bilimleri dersi (3, 4, 5, 6, 7, ve 8. sinıflar) öğretim programı. Ankara, (2013).

[34] MEB [Türkiye Cumhuriyeti Milli Eğitim Bakanlığ1], Fen bilimleri dersi öğretim programı (Illkokul ve Ortaokul 3, 4, 5, 6, 7, ve 8. Sinıflar). Ankara, (2018). 
[35] Mickey, C. D., Chemical equilibrium, Journal of Chemical Education, 57(11), 801, (1980).

[36] Morgil, İ., Erdem, E. \& Yılmaz, A., Kimya eğitiminde kavram yanılgıları, Hacettepe Üniversitesi Ĕgitim Fakültesi Dergisi, 25, 246-255, (2003).

[37] Padilla, M. J., The science process skills. Research matters-To the science teacher, No. 9004. Reston, VA: National Association for Research in Science Teaching (NARST). http://www.narst.org/publications/research/skill.cfm, (1990).

[38] Papageorgiou, G., Stamovlasis, D. \& Johnson, P. M., Primary teachers' particle ideas and explanations of physical phenomena: effect of an inservice training course, International Journal of Science Education, 32(5), 629-652, (2010).

[39] Pimental G. C. (1966). Chemistry: An experimental science. Chemical education material study. London: W. H. Freeman and Company.

[40] Rusçuklu, P. \& Özdilek, Z., Bütünleştirilmiş anlaşma halkaları ve TGA yönteminin çözünürlüğe etki eden faktörler konusundaki kavramsal anlamaya etkisi, Eskişehir Osmangazi Üniversitesi Sosyal Bilimler Dergisi, 20, 621-648. DOI: 10.17494/ogusbd.553783, (2019).

[41] Sarıtaş, D., \& Tufan, Y., Macro and micro knowledge levels for chemistry teaching in terms of reductionism, Gazi Eğitim Fakültesi Dergisi, 33(2),165192, (2013).

[42] Schollum, B. \& Osborne, R., Relating the new to the familiar. In R. Osborne \& P. Freyberg (eds.), Learning in Science. Heinemann: London, (1985).

[43] Senemoğlu, N., Gelişim öğrenme ve öğretim: Kuramdan uygulamaya. Ankara: Pegem Akademi, (2011).

[44] Sienko M, J. and Plane R, A., Chemistry: Principles and Properties, Tosho Printing Co., LTD., Tokyo 1966.

[45] Smith, K., Edionwe, E. \& Michel, B., Conductimetric titrations: A predict observe explain activitiy for general chemistry, Journal of Chemical Education, 87(11), 1217-1221, (2010).

[46] Sökmen, N., Bayram, H. \& Yımaz, A., 5., 8. ve 9. sınıf öğrencilerinin fiziksel ve kimyasal değişim kavramlarını anlama seviyeleri, M. Ü. Atatürk Eğitim Fakültesi Eğitim Bilimleri Dergisi, 12, 261-266, (2000).

[47] Stavridou, H. \& Solomonidou, C., Physical phenomena-chemical phenomena: do pupil make the distinction?, International Journal of Science Education, 11(1), 83-92, (1989).

[48] Tan, M. \& Temiz, B. K., Fen öğretiminde bilimsel süreç becerilerinin yeri ve önemi, Pamukkale Üniversitesi Eğitim Fakültesi Dergisi, 1(13), 89-101, (2003).

[49] Tsaparlis, G., Chemical phenomena versus chemical reactions: do students make the connection?, Chemistry Education: Research and Practice, 4(1), 31-43, (2003).

[50] White, R. \& Gunstone, R, Probing understanding, (first edition), The Falmer Press: London and New York, (1992).

[51] Yalçın-Çelik, A., Turan-Oluk N., Üner, S., Ulutaş, B., \& Akkuş, H., Kimya öğretmen adaylarının asitlik kavramı ile ilgili anlamalarının çizimlerle değerlendirilmesi, Ahi Evran Üniversitesi Kırşehir Eğitim Fakültesi Dergisi (KEFAD), 18, 103-124, (2017). 


\section{Ek-1 Gösteri deneyleri}

\section{Deney 1}

Deneyin Amacı: Süzgeç kağıdının $0.1 \mathrm{M} \mathrm{NaOH}$ ve $0.1 \mathrm{M} \mathrm{HCl} \mathrm{çözeltilerindeki} \mathrm{davranışını}$ gözlem yoluyla incelemek.

Araç ve Gereçler: İki adet deney tüpü veya iki adet $50 \mathrm{~mL}$ lik beher.

Kimyasal Maddeler: İki parça süzgeç kâğıdı, $0.1 \mathrm{M} \mathrm{NaOH}$ ve $0.1 \mathrm{M} \mathrm{HCl} \mathrm{çözeltisi.}$

Deneysel Yöntem: İki parça süzgeç kâğıdı alınır ve rengi not edilir. Süzgeç kağıtlarından birisi $0.1 \mathrm{M} \mathrm{NaOH}$ çözeltisine, diğeri ise $0.1 \mathrm{M} \mathrm{HCl}$ çözeltisine daldırılır ve renk değişimi not edilir.

\section{Deney 2}

Deneyin Amacı: Turnusol kağıdının $0.1 \mathrm{M} \mathrm{NaOH}$ ve $0.1 \mathrm{M} \mathrm{HCl} \mathrm{çözeltilerindeki} \mathrm{renk}$ değişimini belirlemek

Araç ve Gereçler: iki adet deney tüpü veya iki adet $50 \mathrm{~L}$ lik beher.

Kimyasal Maddeler: İki parça mavi turnusol kağıdı, iki parça turnusol kağıdı, $0.1 \mathrm{M}$ $\mathrm{NaOH}$ ve $0.1 \mathrm{M} \mathrm{HCl} \mathrm{çözeltisi.}$

Deneysel Yöntem: Birinci aşamada, araştırmacı tarafından önceden hazırlanmış $0.1 \mathrm{M}$ $\mathrm{NaOH}$ ve $0.1 \mathrm{M} \mathrm{HCl}$ çözeltilerinin 5.0 mL'lik kısımları alınır. $\mathrm{NaOH}$ ve $\mathrm{HCl}$ etiketli iki deney tüpüne ayrı ayrı doldurulur. İki parça mavi turnusol kâğıdı alınır. Turnusol kağıdının biri $0.1 \mathrm{M} \mathrm{NaOH}$ çözeltisine, diğeri ise $0.1 \mathrm{M} \mathrm{HCl}$ çözeltisine daldırılır. İkinci aşamada, birinci aşamadaki deneme bir kez de kırmızı turnusol kâğıdı ile tekrar edilir. Mavi ve kırmızı turnusol kağıdı ve $0.1 \mathrm{M} \mathrm{NaOH}$ ve $0.1 \mathrm{M} \mathrm{HCl}$ çözeltilerindeki görüntüleri sırasıyla Şekil 1a-1b ve Şekil 2a-2b'de verilmiştir.

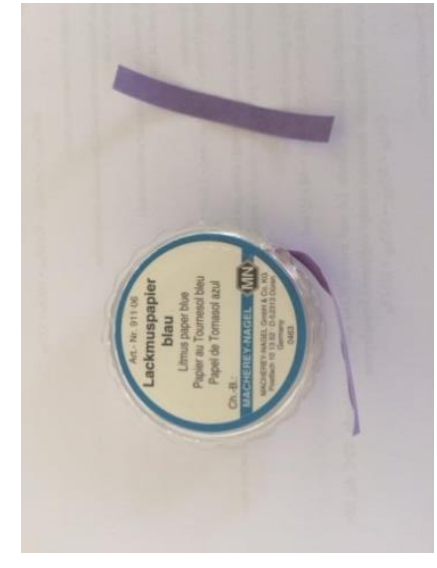

(a)

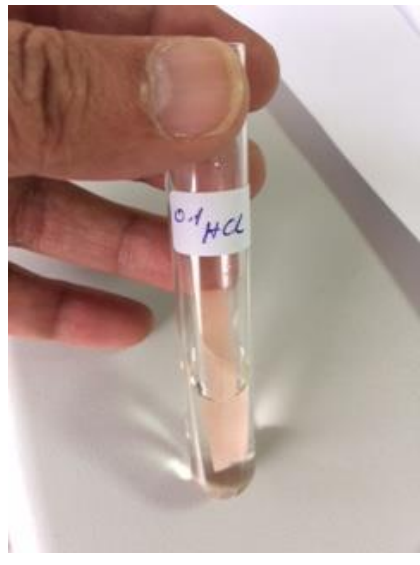

(b)

Şekil 1. (a) Mavi turnusol kağıdının görüntüsü (b) $0.1 \mathrm{M} \mathrm{HCl}$ çözeltisindeki görüntüsü. 


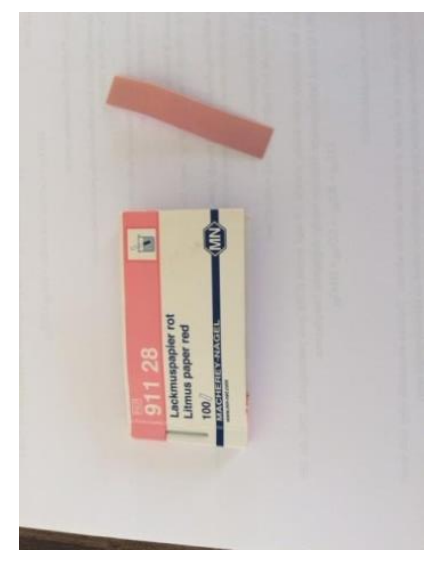

(a)

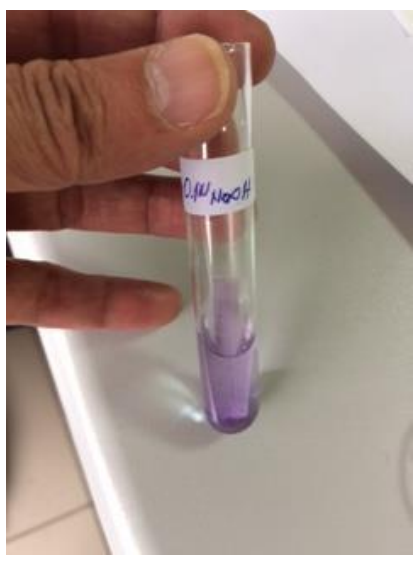

(b)

Şekil 2. (a) Kırmızı turnusol kağıdının görüntüsü (b) $0.1 \mathrm{M} \mathrm{NaOH}$ çözeltisindeki görüntüsü.

\section{Deney 3}

Deneyin Amacı: Mavi ve kırmızı turnusol kağıdının $0.1 \mathrm{M} \mathrm{NaOH}$ ve $0.1 \mathrm{M} \mathrm{HCl}$ çözeltilerindeki tersinir renk değişimini gözlem yoluyla incelemek.

Araç ve Gereçler: İki adet deney tüpü veya iki adet 50 L lik beher.

Kimyasal Maddeler: Bir parça mavi turnusol kağıdı, bir parça kırmızı turnusol kağıdı, 0.1 $\mathrm{M} \mathrm{NaOH}$ ve $0.1 \mathrm{M} \mathrm{HCl}$ çözeltisi.

Deneysel Yöntem: Bu gösteri deneyi üç aşamadan oluşmaktadır. Birinci aşamada, mavi turnusol kağıdı önce $0.1 \mathrm{M} \mathrm{HCl}$ çözeltisine, sonra da $0.1 \mathrm{M} \mathrm{NaOH}$ çözeltisine daldırılır ve turnusol kağıdının her iki çözeltideki rengi belirlenir. İkinci aşamada, $0.1 \mathrm{M} \mathrm{NaOH}$ çözeltisindeki turnusol kağıdı çıkartılır, önce $0.1 \mathrm{M} \mathrm{HCl} \mathrm{çözeltisine} \mathrm{sonra} \mathrm{da} 0.1 \mathrm{M} \mathrm{NaOH}$ çözeltisine daldırılır ve her iki çözeltide turnusol kağıdının rengi belirlenir. Son olarak üçüncü aşamada, $0.1 \mathrm{M} \mathrm{NaOH}$ çözeltisindeki turnusol kağıdı çıkartılır ve tekrardan önce $0.1 \mathrm{M} \mathrm{HCl}$ çözeltisine sonra da $0.1 \mathrm{M} \mathrm{NaOH}$ çözeltisine daldırılır ve her iki çözeltide turnusol kağıdının rengi belirlenir. Aynı uygulama bir kez de kırmızı turnusol kağıdı ile önce $0.1 \mathrm{M} \mathrm{NaOH}$ çözeltisine sonra $0.1 \mathrm{M} \mathrm{HCl} \mathrm{çözeltisine} \mathrm{daldırılarak} \mathrm{tekrar} \mathrm{edilir.}$

\section{Deney 4}

Deneyin Amacı: Turnusol testi ile içeriği bilinmeyen örnek çözeltilerin asidik ve bazik özelliğini belirlemek.

Araç ve Gereçler: Dört adet deney tüpü veya dört adet 50 L lik beher.

Kimyasal Maddeler: İki parça mavi turnusol kağıdı, iki parça kırmızı turnusol kağıdı, biri asidik $(0.1 \mathrm{M} \mathrm{HCl})$ diğeri bazik $(0.1 \mathrm{M} \mathrm{NaOH})$ iki bilinmeyen örnek çözeltisi.

Deneysel Yöntem: Araştırmacılar tarafından önceden hazırlanmış $0.1 \mathrm{M} \mathrm{NaOH}$ çözeltisi (1) ile $0.1 \mathrm{M} \mathrm{HCl}$ çözeltisi (2) ile kodlanır. (1) ve (2) örnek çözeltilerinin 5.0 mL'lik kısımları alınır ve ayrı ayrı iki deney tüpüne doldurulur ve deney tüpleri etiketlenir. Her iki deney tüpündeki çözeltiye mavi turnusol kâğıdı daldırılır. Aynı deneysel etkinlik bir kez de kırmızı turnusol kâğıdı ile tekrarlanır. Deneysel etkinliklerde, mavi turnusol 
kâğıdının (1) ve (2) nolu örnek çözeltilerindeki görüntüleri Şekil 3a-3b de, kırmızı turnusol kâğıdının (1) ve (2) nolu örnek çözeltilerindeki görüntüleri Şekil 4a-4b de verilmiştir.

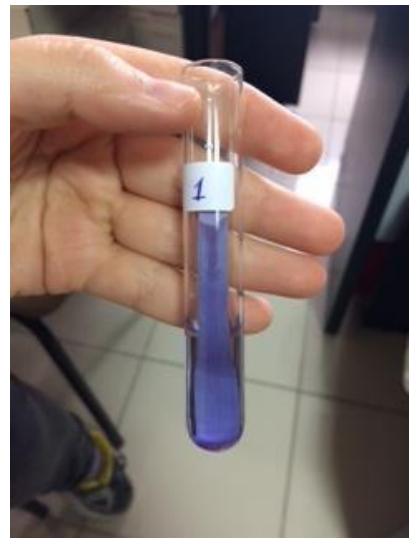

(a)

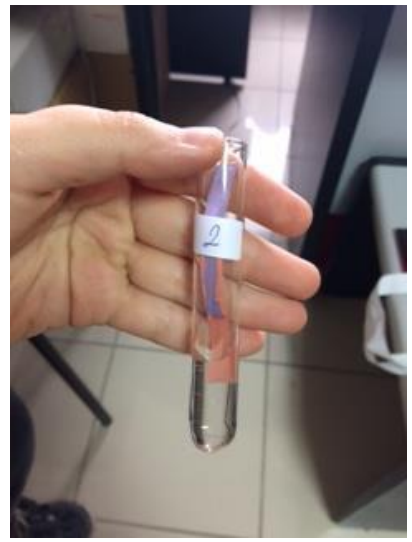

(b)

Şekil 3. (a) Mavi turnusol kâğıdının (1) kodlu örnek çözeltisindeki görüntüsü. (b) Mavi turnusol kâğıdının (2) kodlu örnek çözeltisindeki görüntüsü.

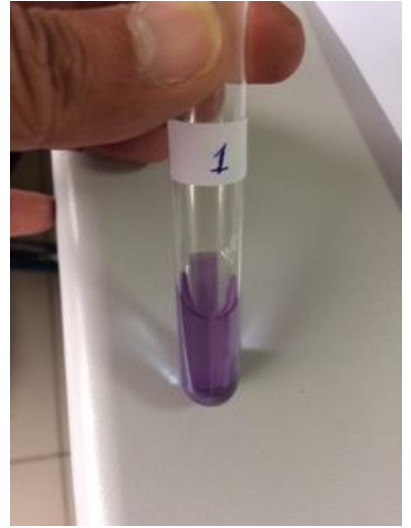

(a)

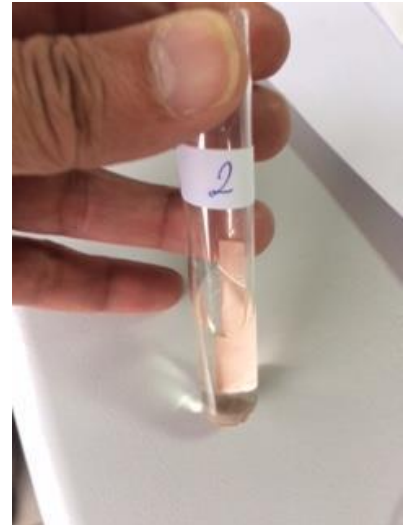

(b)

Şekil 4. (a) Kırmızı turnusol kâğıdının (1) kodlu örnek çözeltisindeki görüntüsü. (b) Kırmızı turnusol kâğıdının (2) kodlu örnek çözeltisindeki görüntüsü.

\section{Genel Öğretmen Yönergesi}

Öğretmen deney öncesinde öğrencileri deneyin amacı konusunda bilgilendirmeli ve öğrencilerin sistematik bir şekilde gözlem notlarını almaya yönlendirmelidir. Bunun için deneylerdeki her işlem basamağının dikkate alındığı deney gözlem formu hazırlayabilir.

\section{Ek 2 Teorik bilgiler}

Etkinliğin özellikle mikro düzeylerinde öğrenciye sunulacak teorik bilgilerin ana çerçevesi aşağıda verilmiştir.

\section{Denge Teorisi}

Dinamik denge teorisine göre, çoğu kimyasal tepkime tam olarak gerçekleşmez. Bunun yerine, tepkimeye girenler ve oluşan ürünler arasında girenlerin ürünlere, ürünlerin ise girenlere dönüşüm hızının eşit olduğu ve tersinirlik özelliği bağlamında dönüşümün 
devam ettiği bir dinamik denge kurulur. Diğer yandan, sabit sicaklıkta, kapalı bir sistemde tepkimeye girenler ve oluşan ürünler sistemde iken, renk şiddeti, buhar basıncı, $\mathrm{pH}$ gibi makroskobik bir özelliğin sabit kalması moleküler düzeyde dinamik dengenin kurulduğunun göstergesidir (Mickey, 1980). Genel bir denge tepkimesi (1) eşitliği ile modellenebilir.

$$
\mathrm{aA}_{(\mathrm{g})}+\mathrm{bB}_{(\mathrm{g})} \underset{\mathrm{c}}{\stackrel{\mathrm{c}}{(\mathrm{g})}}+\mathrm{dD}_{(\mathrm{g})}
$$

Kimyasal kinetik teori bağlamında kütlenin tesiri kanununa göre, ileri tepkimenin hızı için (2) eşitliği ve geri tepkimenin hızı için ise (3) eşitliği yazılabilir.

$$
\begin{aligned}
& \mathrm{V}_{\mathrm{i}}=\mathrm{k}_{\mathrm{i}}[\mathrm{A}]^{\mathrm{a}} \mathrm{x}[\mathrm{B}]^{\mathrm{b}} \\
& \mathrm{V}_{\mathrm{g}}=\mathrm{k}_{\mathrm{g}}[\mathrm{C}]^{\mathrm{c}} \mathrm{x}[\mathrm{D}]^{\mathrm{d}}
\end{aligned}
$$

Kimyasal termodinamik teori bağlamında kütlenin tesiri kanununa göre, denge sabiti için

(4) eşitliği yazılabilir.

$$
\mathrm{k}_{\mathrm{d}}=\frac{[\mathrm{C}]^{\mathrm{c}}[\mathrm{D}]^{\mathrm{d}}}{[\mathrm{A}]^{\mathrm{a}}[\mathrm{B}]^{\mathrm{b}}}
$$

Le Chaletlier İlkesine göre, dengedeki bir sisteme bir etki yapıldığında, sistem buna tepki gösterir. Bu durumda, denge konumu değişir ve tekrar denge kuruluncaya kadar, tepkime girenlerden ürünler yönüne doğru veya ürünlerden girenlere doğru kayar (Sienko \& Plane, 1966; Pimental, 1966).

\section{Lowry Bronsted Teorisi}

Lowry-Bronsted teorisine göre, bir asit ile bir baz, başka bir asit ile başka bir baz oluşturmak üzere, proton transferiyle reaksiyona girer. Genel bir asit-baz tepkimesi için (5) eşitliği yazılabilir.

$$
\operatorname{Asit}_{(1)}+\mathrm{Baz}_{(2)} \underset{\leftarrow}{\rightarrow} \text { Asit }_{(2)}+\mathrm{Baz}_{(1)}
$$

Zayıf asidik özellikteki bir belirtecin sudaki iyonlaşma tepkimesi için Lowry-Bronsted teorinse göre modellenirse, (6) tepkimesi yazılabilir.

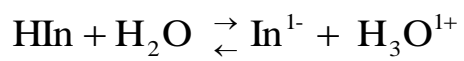

Bu tepkimede, HIn proton transfer eden, In $^{1-}$ ise proton kabul eden türlerdir. HIn formu, $\mathrm{In}^{1-}$ formunun konjuge asidi, $\mathrm{In}^{1-}$ formu ise HIn formunun konjuge baz formudur. HIn ve $\mathrm{In}^{1-}$ ise konjuge asit-baz çifti olarak ifade edilir (Kolb, 1979; Sienko, \& Plane, 1966; Pimental, 1966).

\section{pH belirteçleri (indikatör)}

Asit-baz belirteçleri ( $\mathrm{pH}$ belirteçleri) zayıf asitler veya zayıf bazlardır. Zayıf asit ve bazlar sulu çözeltilerinde dinamik denge tepkimesi oluşturarak iyonlaşırlar (Kolb, 1979). Belirteç zayıf asit ise (7) de verilen denge tepkimesi ve denge sabiti eşitliği yazılabilir. 


$$
\mathrm{HIn}+\mathrm{H}_{2} \mathrm{O} \underset{\leftarrow}{\rightarrow} \mathrm{In}^{1-}+\mathrm{H}_{3} \mathrm{O}^{1+} \quad \quad \mathrm{k}_{\mathrm{HIn}}=\frac{\left[\mathrm{In}^{1-}\right]\left[\mathrm{H}_{3} \mathrm{O}^{1+}\right]}{[\mathrm{HIn}]}
$$

Bir belirtecin konjuge asit (HIn) formunun rengi, konjuge baz $\left(\mathrm{In}^{1-}\right)$ formunun renginden farklıdır. Çözelti yeterince asidik olduğunda, belirteç ağırlıklı olarak asit formunda (HIn) ve asit formun rengine sahip olur. Çözelti yeterince bazik olduğunda ise ağırlıklı olarak baz formuna $\left(\mathrm{In}^{1-}\right)$ ve baz formun rengine dönüşür. Kural olarak, insan gözü $\frac{[\mathrm{HIn}]}{\left[\mathrm{In}^{1-}\right]} \geq 10$ iken asit formunun rengini, $\frac{[\mathrm{HIn}]}{\left[\mathrm{In}^{1-}\right]} \leq 0.1$ iken baz formunun rengini alg1lar (Kolb, 1979).

Zayıf asit olan bir belirtecin sulu çözeltisinde, $\mathrm{pH}, \mathrm{k}_{\mathrm{HIn}}$ ve [HIn]/[In $\left.{ }^{1-}\right]$ arasındaki ilişki (8) ile verilir.

$$
\mathrm{pH}=\mathrm{pk}_{\mathrm{HIn}}-\log \frac{[\mathrm{HIn}]}{\left[\mathrm{In}^{1-}\right]}
$$

Belirtecin asit formunun renginden baz formunun rengine geçişi için $\mathrm{pH}$ aralığ $\mathrm{pH}=\mathrm{pk}_{\mathrm{HIn}} \pm 1$ dir. Diğer yandan asit formunun rengi $\mathrm{pH} \leq \mathrm{pk}_{\mathrm{HIn}}-1$ iken, baz formunun rengi ise $\mathrm{pH} \geq \mathrm{pk}_{\mathrm{HIn}}+1$ iken gözlenir (Kolb, 1979).

\section{Renk, Renk Değişimi ve Tersinir Renk Değişimi}

Renk, bir maddenin kendine özgü bir fiziksel özelliğidir. Birçok bileşik veya çözeltisi insan gözüne duyarlı olan, 1şık spektrumunun $400 \mathrm{~nm}$ ve $700 \mathrm{~nm}$ arasındaki dalga boyuna sahip görünür bölge 1şınının bir kısmını absorbladığı için renklidir. Bu bağlamda bir maddenin rengi, maksimum absorbsiyon yaptığ 1 1şığın dalga boyu $\left(\lambda_{\max }\right)$ ile ilişkilidir. Başka bir deyişle, bir maddenin renginin nicel ölçüsü, $\lambda_{\max }$ tır. Aynı şartlarda iki bilinmeyen maddenin (elmas ve grafit gibi allotroplar hariç) aynı mı yoksa farklı $\mathrm{m} 1$ olduğunu belirlemek amacıyla kullanılabilir bir nitel veridir.

Bir maddenin fiziksel veya kimyasal özelliğinin değişimi, moleküler düzeyde atomik veya moleküler absorbsiyonun gerçekleştiği atom, iyon veya molekülün $\lambda_{\max }$ in değişimine, sonuç olarak da maddenin renginin değişimine neden olabilir. Bu bağlamda bir maddeye bir etki yapıldığında, gözlem yoluyla belirlenen renk değişimi, bazı durumlarda fiziksel değişime bazı durumlarda ise kimyasal değişime dayanır. Bu nedenle renk değişimi, maddenin fiziksel değişime mi yoksa kimyasal değişime mi uğradığının nitel göstergesidir.

Bir maddeye bir etki yapıldığında renk değişiyor, etki ortadan kaldırıldığında madde tekrar eski rengin dönüşüyorsa, başka bir deyişle etki bağlamında tersinir renk değimi gözleniyorsa, bu durum tersinir fiziksel değişim veya tersinir kimyasal değişim gerçekleştiğinin göstergesidir. Hal değişimleri bağlamında iyodun süblimleşmesiresüblimleşmesi, çözünme bağlamında iyodun etil alkol veya kloroformdaki çözünmesi tersinir fiziksel değişim örneği iken (Ergül, 2014a; Ergül, 2014b), turnusol kağıdının asitbaz etkisi bağlamında tersinir renk değişimi tersinir kimyasal değişim örneğidir. 


\section{Fiziksel ve Kimyasal Değişim}

Fen öğretiminde, fiziksel ve kimyasal değişim öğretilmesi gereken en temel kavramlardandır. Gensler (1970) de fiziksel özellik, kimyasal özellik, fiziksel değişim ve kimyasal değişim kavramlarını incelemiştir. Buna göre boyut, şekil, fiziksel hal, erime noktası, sıcaklık, renk, yoğunluk, tat, koku, viskozite, mıknatıslanma, sertlik, kırılganlık, 1s1 iletkenliği, elektriksel iletkenlik maddenin fiziksel özelliklerindendir. Aynı zamanda ilgili makalede fiziksel değişimde maddenin yalnızca dış yapısının değiştiği ve değişme sonucunda yeni bir maddenin oluşmadığı belirtilmiştir. Maddenin hal değişimi (erimedonma, buharlaşma-yoğunlaşma ve süblimleşme olayları), çözünme-kristallenme, maddenin iki basit parçaya ayrılması (kâğıdın yırtılması), ısı ile genişleme gibi olaylar ise fiziksel değişim örnekleridir. Kimyasal özellik ise maddenin içyapısı ile ilgili özellikler olup yanabilirlik, elektron alma-verme, asitlerle veya bazlarla etkileşme gibi durumları kapsar. Yine Gensler, kimyasal değişimin, maddenin içyapısının değişmesiyle gerçekleştiğini ve değişim sonucunda yeni bir maddenin oluştuğunu belirtmiştir. Oksitlenme, yanma, asit-baz tepkimeleri ve indirgenme-yükseltgenme tepkimeleri, besin maddelerinin parçalanması, fotosentez, elektroliz gibi olaylar kimyasal değişim örnekleridir. Diğer yandan, fiziksel değişim kavramının öğretiminde; mumun veya buzun erimesi, kimyasal değişim kavramının öğretiminde; mumun yanması veya demirin paslanmasının favori örnekler olduğu bu nedenle basit ve herkes tarafindan bilinen bu örneklerin verilmesi gerektiği de vurgulanmıştır. 